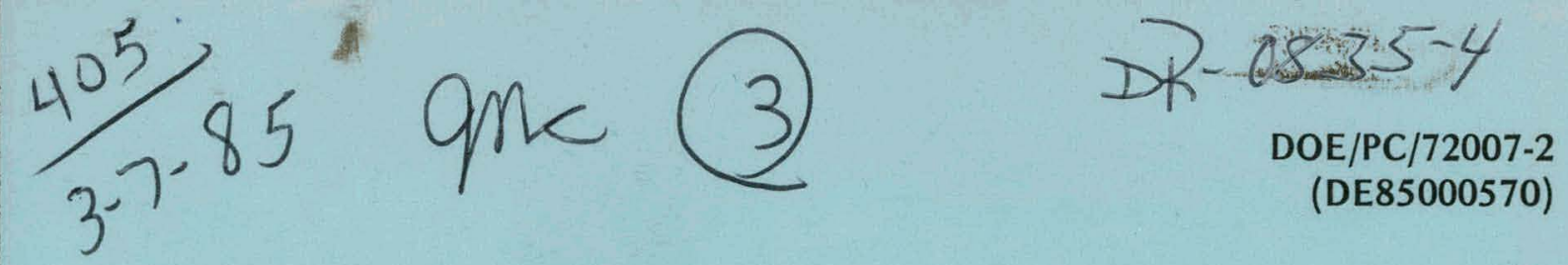

\title{
Energy
}

\section{ULTRA-FINE COAL CHARACTERIZATION}

Second Quarterly Report for the Period June 1-August 31, 1984

By

F. J. Smit

J. R. Odekirk

September 10, 1984

Work Performed Under Contract No. AC22-84PC72007

For

U. S. Department of Energy

Pittsburgh Energy Technology Center

Pittsburgh, Pennsylvania

By

AMAX Extractive Research \& Development, Inc.

Golden, Colorado

Technical Information Center

Office of Scientific and Technical Information

United States Department of Energy 


\section{DISCLAIMER}

This report was prepared as an account of work sponsored by an agency of the United States Government. Neither the United States Government nor any agency Thereof, nor any of their employees, makes any warranty, express or implied, or assumes any legal liability or responsibility for the accuracy, completeness, or usefulness of any information, apparatus, product, or process disclosed, or represents that its use would not infringe privately owned rights. Reference herein to any specific commercial product, process, or service by trade name, trademark, manufacturer, or otherwise does not necessarily constitute or imply its endorsement, recommendation, or favoring by the United States Government or any agency thereof. The views and opinions of authors expressed herein do not necessarily state or reflect those of the United States Government or any agency thereof. 


\section{DISCLAIMER}

Portions of this document may be illegible in electronic image products. Images are produced from the best available original document. 


\section{DISCLAIMER}

This report was prepared as an account of work sponsored by an agency of the United States Government. Neither the United States Government nor any agency thereof, nor any of their employees, makes any warranty, express or implied, or assumes any legal liability or responsibility for the accuracy, completeness, or usetulness of any information, apparatus, product, or process disclosed, or represents that its use would not infringe privately owned rights. Reference herein to any specific commercial product, process, or service by trade name, trademark, manufacturer, or otherwise does not necessarily constitute or imply its endorsement, recommendation, or favoring by the United States Government or any agency thereof. The views and opinions of authors expressed herein do not necessarily state or reflect those of the United States Government or any agency thereof.

This report has been reproduced directly from the best available copy.

Available from the National Technical Information Service, U. S. Department of Commerce, Springfield, Virginia 22161.

Price: Printed Copy A03

Microfiche A01

Codes are used for pricing all publications. The code is determined by the number of pages in the publication. Information pertaining to the pricing codes can be found in the current issues of the following publications, which are generally available in most libraries: Energy Research Abstracts (ERA); Government Reports Announcements and Index (GRA and I); Scientific and Technical Abstract Reports (STAR); and publication NTIS-PR-360 available from NTIS at the above address. 
DOE/PC/72007-2

(DE85000570)

Distribution Category UC-90b

\title{
ULTRA-FINE COAL CHARACTERIZATION
}

\section{ND QUARTERLY REPORT}

\author{
JUNE 1, 1984 - AUGUST 31, 1984 \\ F.J. Smit and J.R. Odekirk \\ September 10, 1984
}

AMAX Extractive Research \& Development, Inc. 5950 McIntyre Street

Golden, C0 80403

Prepared for

The United Statcs Dcpartment of Enireyy

Pittsburgh Energy Technology Center

Pittsburgh, PA

Under Contract DE-AC22 -84PC72007 


\begin{abstract}
This report covers the second quarter of activity on the project to characterize the mineral-matter liberation and the beneficiation of ultra-fine coal. So far the work has been confined to the base-case coal from the Illinois No. 6 seam. Eight other coals will be examined later in the program. The work accomplished this quarter, and described in this report, included determination of additional bulk properties of the coal, an examination of the mineral-matter and mineral associations in the coal, and the preparation and washability testing of ultra-fine, minus 44-micrometer (325-mesh) coal for liberation studies.
\end{abstract}




\section{TABLE OF CONTENTS}

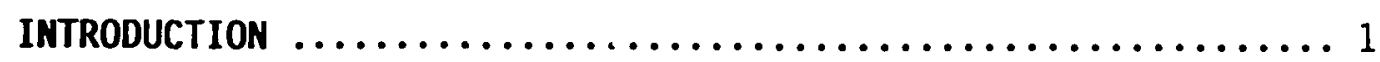

BULK PROPERTIES OF ILLINOIS NO. 6 COAL $\ldots \ldots \ldots \ldots \ldots \ldots \ldots$

MINERAL-MATTER IDENTIFICATION AND LIBERATION $\ldots \ldots \ldots \ldots \ldots \ldots 3$

MINERALOGICAL EXAMINATION $\ldots \ldots \ldots \ldots \ldots \ldots \ldots \ldots \ldots \ldots \ldots \ldots \ldots \ldots$

ULTRA-FINE GRINDING FOR LIBERATION $\ldots \ldots \ldots \ldots \ldots \ldots \ldots \ldots \ldots$

LIBERATION STUDIES BY HEAVY-LIQUID SEPARATION $\ldots \ldots \ldots \ldots \ldots \ldots$.......

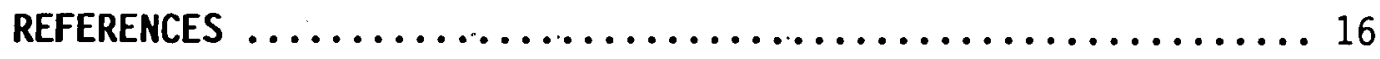

APPENDIX A

VITRINITE REFLECTANCE MEASUREMENTS $\ldots \ldots \ldots \ldots \ldots \ldots \ldots \ldots, 18$

APPENDIX B

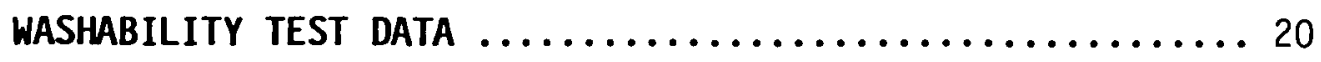

APPENDIX C

MACERAL/MINERAL DISTRIBUTION TABLES $\ldots \ldots \ldots \ldots \ldots \ldots \ldots 23$

APPENDIX D

CORRELATION OF STIRRED-BALL MILL GRINDING DATA ......... 30 


\section{LIST OF TABLES}

Page

Table 1

Analyses (Dry Basis) of the Whole-Seam and

Cleaned Illinois No. 6 Coal ........................ 2

Table 2

Macerals and Forms of Mineral-Matter in

$14 M \times 0$ Illinois No. 6 Whole Seam and

Clean Coal ....................................

Table 3

Particle Size Distributions of Illinois

No. 6 Clean Coal Ground for Liberation

Studies ................................... 12

Table 4

Washability of 65 Mesh $\times 0$ Illinois No. 6

Cleaned Coal

Table 5

Washability of 44-Micrometer $\times 0$ Illinois

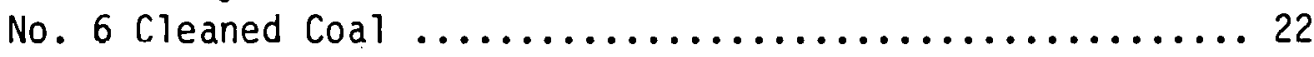

Table 6

Composite Mineralogical Balances for

i4M $x 0$ Whole Seam Illinois No. 6 Coal ................. 24

Table 7

Point-Count Mineralogical Balances for

$14 M \times 100 M$ Whole Seam Illinois No. 6 Coal ............. 25

Table 8

Point-Count Mineralogical Balances for

$100 M \times 0$ Whole Seam Illinois No. 6 Coal .............. 26

Table 9

Composite Mineralogical Balances For

$14 M \times 0$ Illinois No. 6 Clean Coal

Table 10

Point-Count Mineralogical Balances for

$14 M \times 100 M$ Whole Seam Illinois No. 6 Coal 28 


\section{LIST OF TABLES}

Page

Table 11

Point-Count Mineralogical Balances for $100 M \times 0$ Illinois No. 6 Coal

Table 12

Particle Size Distributions of Ground Coal ............. 31

Table 13

Particle Size Distribution 80M $\times 0$ Illinois

No. 6 Feed Coal for Stirred-Ball-Mill

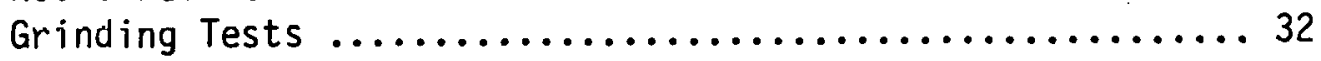




\section{LIST OF FIGURES}

Page

Figure 1

Photomicrograph showing locked pyrite and

mineral-matter filling pore space in fusinite $\ldots . \ldots \ldots \ldots 4$

Figure 2

Photomicrograph showing variable density of

locked pyrite framboids, a fragment of solid

free pyrite, locked mineral-matter lenses

in vitrinite, and locked mineral-matter in

fusinite $\ldots \ldots \ldots \ldots \ldots \ldots \ldots \ldots \ldots \ldots \ldots \ldots \ldots \ldots \ldots$

Figure 3

Photomicrograph showing locked mineral-matter

filling a cleat in vitrinite $\ldots \ldots \ldots \ldots \ldots \ldots \ldots \ldots \ldots$

Figure 4

Photomicrograph showing fragment of trimacerite

with an exinite band and dispersed silt grains .......... 5

Figure 5

Particle Size Distributions of Slurry Increments

Taken During Grinding of 111 inois No. 6 Clean

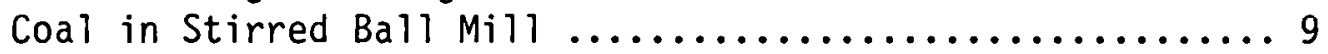

Figure 6

Particle Size Versus Time for Grinding Illinois

No. 6 Clean Coal in a Stirred Ball Mill ................ 10

Figure 7

Plus 20-Micrometer Fraction from Wet Screening

44-Micrometer $x 0$ I11inois No. 6 1.3-Specific-

Gravity Float Coal ............................. 14

Figure 8

20-Micrometer $\times 10$-Micrometer Fraction from

Wet Screening 44-Micrometer $x 0$ Illinois

No. 6 1.3-Specific-Gravity Float Coal 


\section{INTRODUCTION}

This report covers the second quarter of activity on a 30 -month project to characterize the mineral-matter liberation and the beneficiation of ultrafine coal. So far the work has been confined to the base-case coal, an Illinois No. 6 sample from the Delta mine in Saline County east of Marion, Illinois. Eight other coals will be examined later in the program. The work accomplished this quarter, and described in this report, included determination of additional bulk properties of the coal, an examination of the mineral-matter and mineral associations in the coal, and the preparation and washability testing of ultra-fine, minus 44-micrometer (325-mesh) coal for liberation studies.

\section{BULK PROPERTIES OF ILLINOIS NO. 6 COAL}

The bulk properties of the Illinois No. 6 channel sample before and after cleaning in a heayy-media/shaking-table circuit were reported in the 1 st Quarterly Report ${ }^{(1)}$. Table 1 shows some of this data. Low temperature ash, carbonate, and vitrinite reflectivity determinations have been added to the list.

The low temperature ash (LTA) determinations were made by Commercial Testing and Engineering Co. and the residue returned for use in the mineralogical work to be discussed later in this report. At 8.24 weight percent, the LTA was somewhat less than the 8.45 percent mineral-mafter calculated from the Parr formula for establishing the ASTM rank $(2,3)$.

Over 90 percent of the clean-coal macerals were determined, by microscopic point count examination, to be vitrinite. The remaining maceral cortent was divided about evenly between inertinite (fusinite, semifusinite, etc.) and exinite (resinous material and spores).

The optical reflectivity of vitrinite macerals has been related to the degree of aromatization and condensation of structural units which occurred during coaljfication and is regarded by many as the best single parameter of coal rank $(4)$. This Illinois No. 6 coal had a mean maximum reflectance of 0.64 percent which places it in the high volatile "B" bituminous rank $(4)$ and which is lower than the high volatile "A" rank indicated by the calorific measurements for the ASTM procedure ${ }^{(2)}$. The vitrinite reflectivity measurements were done by the Wyoming Analytical Laboratories. Their report is in Appendix A.

A washability test was made on the 65 mesh $\times 0$ clean coal to provide additional baseline separation and liberation data. Results of this work are given in Appendix B. 
Table 1. Analyses (Dry.Basis) of the Whole-Seam and Cleaned Illinois No. 6 Coal

Whole Seam

Proximate Analyses, \%:

Ash

Volatiles

Fixed Carbon.

Fixed Carbon, Dmmfa
19.73

35.88

44.39

57.18

Cleaned Coa

Forms of Sulfur, $\%$ :

Total

Pyrite

3.71

2.29

0.058

Sulfate

1.362

6.74

37.17

56.09

60.92

Organic

11,685

14,557

14,052

2.13

0.71

0.004

1.416

Calorific Value, Btu/lb:

$$
\text { Mafy }_{b}
$$

Mmmf C

64.51

4.45

1.14

3.71

0.07

19.73

6.39

13,952

14,960

14,091

Ultimate Analyses, \%:
Hydrogen
Nitrogen
Chlorine
Ash
Oxygen (by difference)

6.33

0.79

76.97

5.16

1.40

2.13

0.09

6.71

7.51

Equilibrium Moisture, \%

Carbonate $\mathrm{CO}_{2}, \%$

6.83

U. 14

Low Temperature Ash, \%

8.24

Mean Vitrinite Maximum Ref. lectance $\left(R_{0} \max \right)$, \%

0.64

Free Swelling Index

5.5

4.5

Hardgrove Grindability Index

57.7

55.8

\footnotetext{
a Dmmf = Dry, mineral-matter free, Parr Formula, ASTM 0-388

b Maf = Moisture and ash free

c Mmmf $=$ Moist, mineral-matter free, Parr.Formula, ASTM D-388
} 


\section{MINERAL-MATTER IDENTIFICATION AND LIBERATION}

\section{MINERALOGICAL EXAMINATION}

The mineral matter in the Illinois No. 6 coal was identified using X-ray diffraction analysis (XRD) and/or microscopic examination in polished section of low-temperature ash (LTA) residue, density fractions from the washability tests on 14-mesh $\times 0$ whole seam and clean coal, and selected specimens from sections of the coal seam.

Mineral-matter detected in the LTA included quartz, kaolinite, calcite, illite, and pyrite. The percent distribution of these minerals has yet to be determined, pending the selection of an acceptable sample preparation method and suitable mineral standards. Microscopic examination and XRD analysis show that quartz, the most common constituent of the mineral matter, occurs as silt grains associated with lenses, clay seams, and pyrite veins. Kaolinite, the second most common constituent, and illite are associated with lenses and clay seams. Some kaolinite also occurs along cleats with calcite, and in bone seams with quartz. Calcite occurs in cleats and along larger fractures but does not appear to be a constituent of pyritic veins.

Pyrite and marcasite occur in a variety of forms which have been defined for distribution purposes as either framboidal, crystalline, fusinite cellfilling, or vein filling. Marcasite has been included with pyrite and the two were considered and are dealt with as a single constituent. Non-pyritic mineral-matter has been defined as that which occurs in lenses, as dispersed particles, as fusinite cell filling, and as cleat (fracture and vein) filling. The mineral-matter occurrences were selected to aid in characterizing mineral-matter liberation during microscopic examination of polished sections of fractions from the 14 mesh $\times 0$ coal.

Mineral-matter liberation for Illinois No. 6 whole-seam coal and Illinois No. 6 clean coal was determined for $14 \times 100$-mesh and 100-mesh $\times 0$ density separation fractions using a point-count method similar to the method described by Chayes $(5)$ for calculatiny pelruyrdphic modal analysis. Constituents of the point-count analysis include the maceral groups (vitrinite, inertinite, exinite) and mineral-matter. Mineral-matter (excluding pyrite) and pyrite (including marcasite) are accounted for during point-count analysis by their mode of occurrence. Various modes of occurrence for macerals, mineral-matter, and pyrite are exhibited in Figures 1 through 4. Mineral matter and pyrite particles are considered to be liberated (free) if they contain less than 10 percent fine-grained, dispersed macerals. Pointcount analysis data were obtained by traversing a polished section until 1000 data points were collected. Weight percent distributions of the constituents were calculated from the raw point-count data and specific-gravity values 


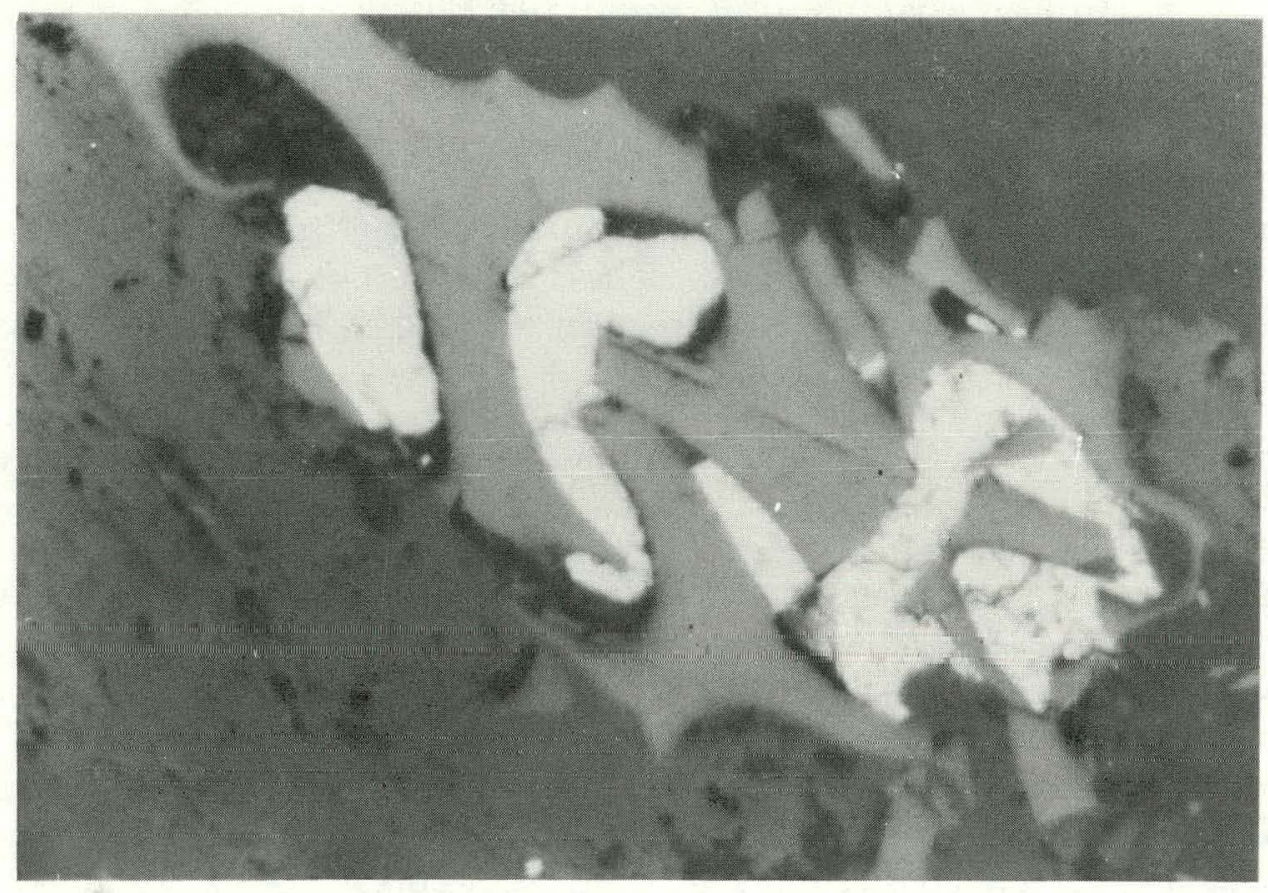

Figure 1. Photomicrograph showing locked pyrite (white) and mineral-matter (dark mottled) filling pore space in fusinite (light gray). 625X

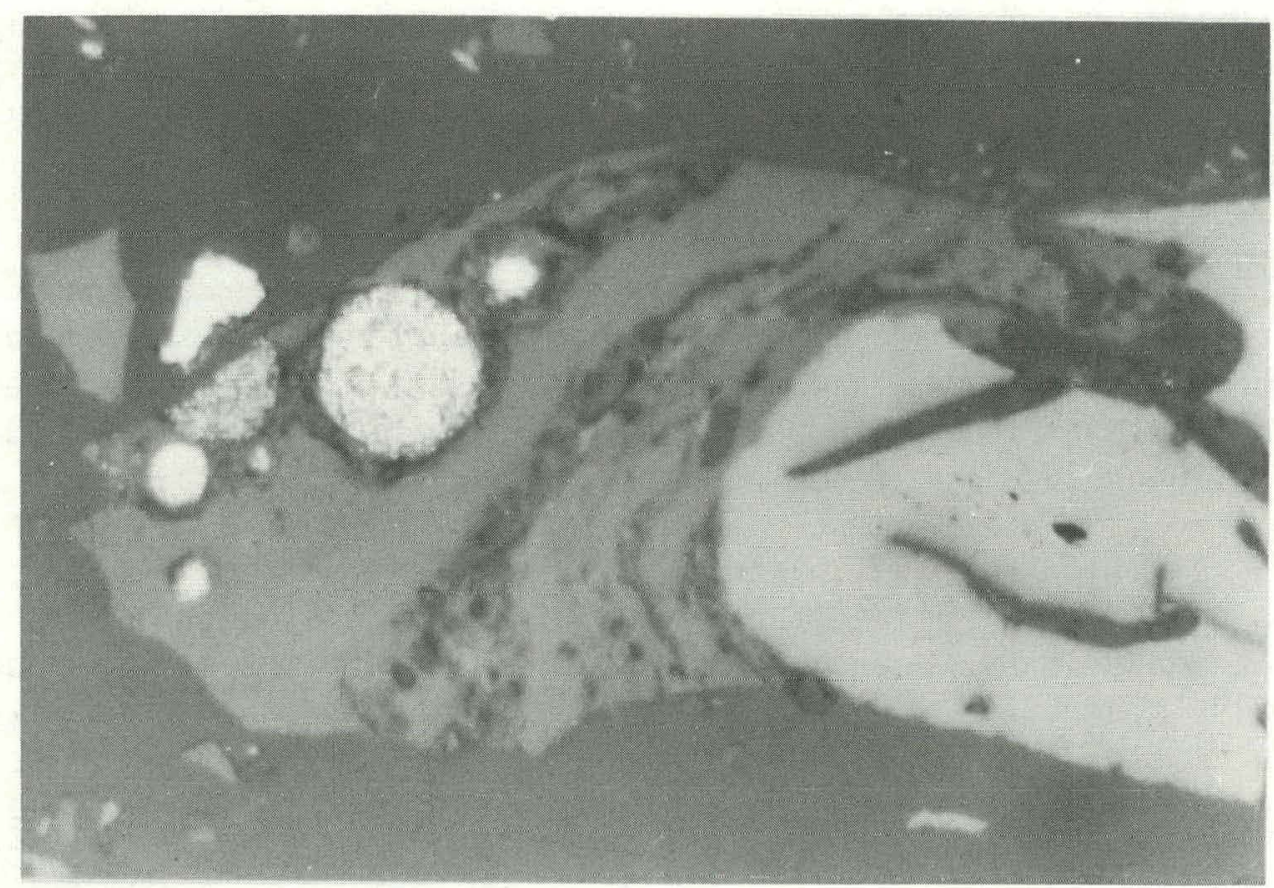

Figure 2. Photomicrograph showing variable density of locked pyrite framboids, a fragment of solid free pyrite, locked mineral-matter lenses in vitrinite (gray), and locked mineral-matter in fusinite. $625 \mathrm{X}$ 


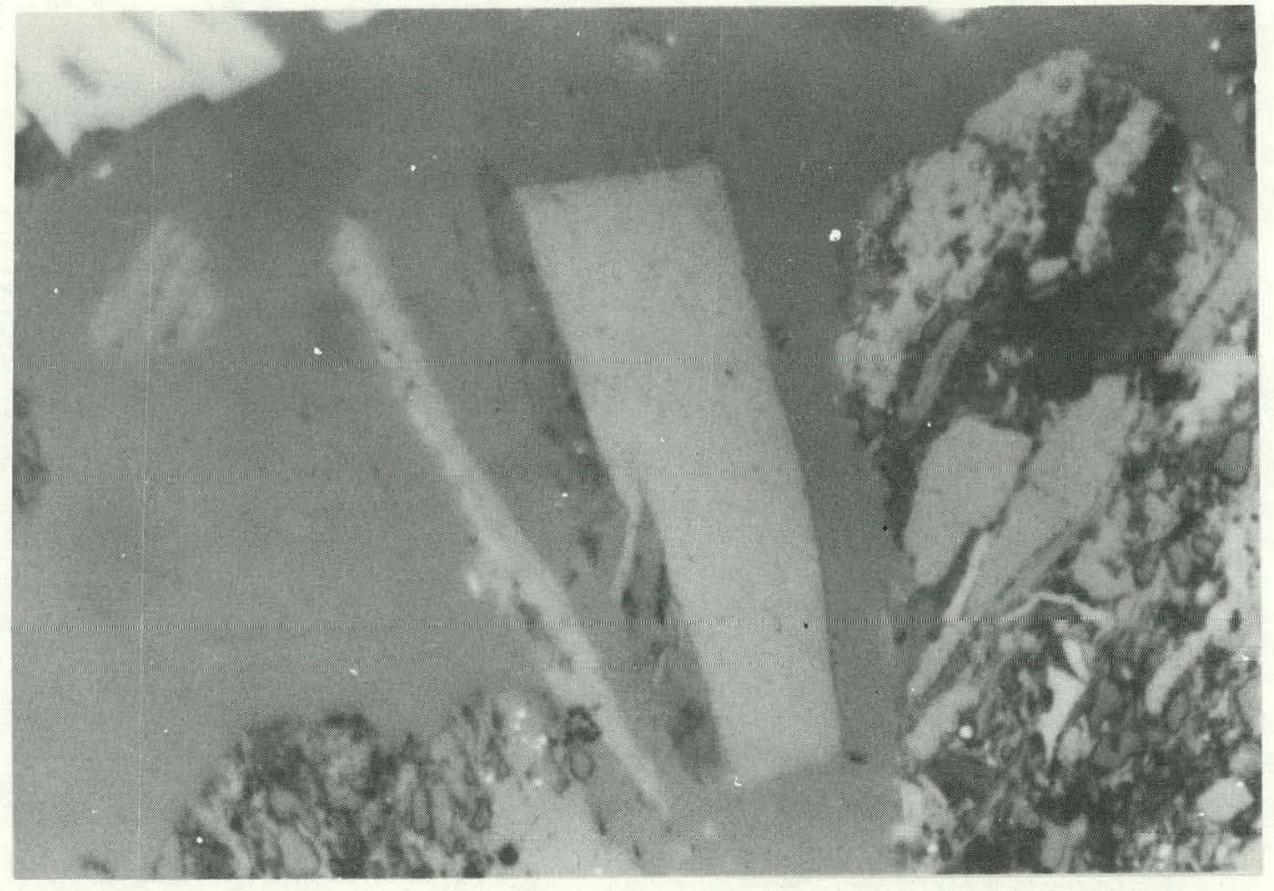

Figure 3. Photomicrograph showing locked mineral-matter filling a cleat in vitrinite (gray). Fragment on the right contains dispersed and lens occurring mineral-matter (dark mottled) in trimacerite. 625x

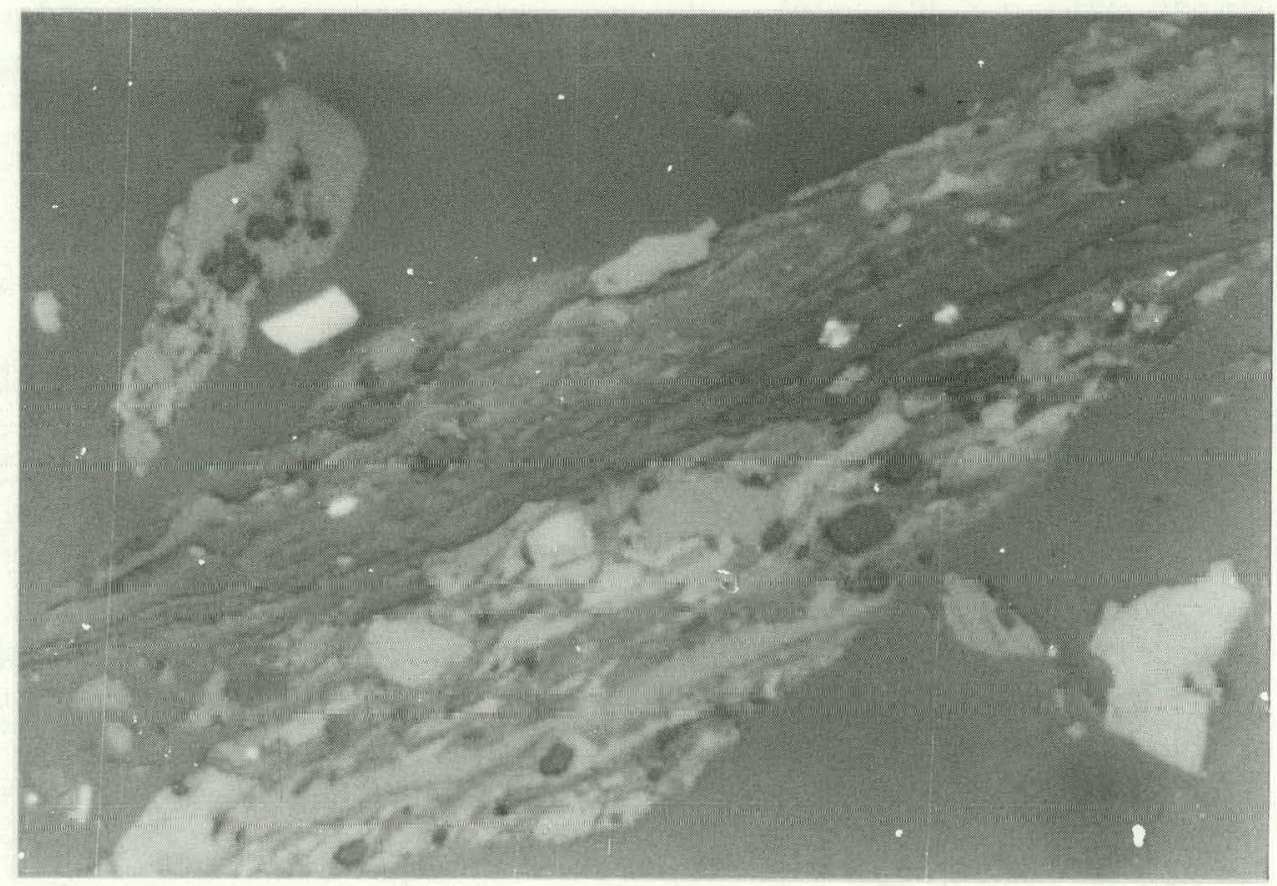

Figure 4. Photomicrograph showing fragment of trimacerite with an exinite band (dark gray) and dispersed silt grains (dark gray with high relief). $625 x$ 
assigned to each constituent. Specific gravity values assigned to the constituents are given in the following list:

\begin{tabular}{lc} 
Constituent & Specific Gravity \\
\cline { 2 - 2 } Vitrinite & 1.32 \\
Inertinite & 1.38 \\
Exinite & 1.21 \\
Mineral-matter & 2.65 \\
Pyrite: framboids & 3.50 \\
Pyrite: crystals, veins & 5.00 \\
Pyrite: free & 4.00
\end{tabular}

The specific gravity values for macerals are those obtained from investigations made by Dyrkacz $(6)$, et al. Specific-gravity values for mineral-matter are average values based on mineral constituents and the apparent bulk-densities from microscopic observation.

The point-count data-reduction was done by computer processing (7) to yield a final weight-percent distribution for each of the various density-size fractions. These data were combined on a weight basis to calculate the constituent distribution for a size-fraction composite. The size-fraction composites were combined on a weight basis and the constituent distributions calculated for the original bulk sample. The maceral and mineral matter distributions obtained by point counting the various fractions and calculated composites of Illinois No. 6 whole seam coal and Illinois No. 6 clean coal are shown in the Maceral/Mineral Distribution Tables in Appendix C.

\section{ULTRA-FINE GRINDING FOR LIBERATION}

Quantitative liberation characteristics of the base-case coal were determined by heavy-liquid washability tests on the finely-ground coal. The ultra-fine grinding was done in a Model S-1 1-1/2-gallon Attritor stirred-bal1 mill similar to that used by Herbst ${ }^{(8)}$. The grinding media was $18.3 \mathrm{~kg}$ of 3/16-inch chrome-steel balls. The stirred-ball mill is a convenient apparatus to use for this work; it is capable of producing a wide range of product finenesses by simply varying the retention time during batch grinding. The 80-mesh $\times 0$ feed coal was slurried in 1.3-specific-gravity Certigrav solution for the grinding. Certigrav solution is a commercial mixture of halogenated hydrocarbons diluted with petroleum hydrocarbons that is commonly used for laboratory heavy-liquid density separation of coal. It was used in preference to water because water would hydrate the clays and dissolve any salts from the coal. These salts and clay would cement the coal particles together later when the samples are dried. 
The distributions of the coal macerals and the forms of mineral-matter and pyrite in the 14-mesh $x 0$ whole seam and clean coal are shown in Table 2. Apparently the cleaning, which was done on the $1 / 2$-inch $\times 0$ coal, was particularly effective for rejecting lenses of mineral matter and clusters of framboidal pyrite. Crushing the $1 / 2$-inch $\times 0$ clean coal to 14 mesh did not free very much additional pyrite and other mineral matter. Except for that labeled "free", the forms of mineral-matter and pyrite listed in Table 2 are a]l locked with coal macerals.

Table 2. Macerals and Forms of Mineral-Matter in $14 \mathrm{M} \times 0$ I11 inois No. 6 Whole Seam and Clean Coal

Component

Vitrinite

Inertinite

Exinite

Non-Pyrite Mineral-Matter:

Lenses

Dispersed

W/Fusinite

Cleats

Free

Pyrite:

Framboids

Crystals

W/Fusinite

Veins

Free

Total
Weight, Percent

Whole Seam Clean Coal

68.0

83.5

5.0

4.5

3.3

3.9

5.7

1.8

5.3

2.8

1.4

0.8

0.6

0.7

4.8

0.7

2.4

0.9

0.5

0.1

0.2

$\mathrm{Tr}$

0.7

0.1

2.2

0.1

100.0 
A ratio of 750 grams of coal to 2.0 liters of Certigrav (22 percent by volume) was used for the initial tests but it was necessary to reduce the ratio to 375 grams of coal to 2.0 liters of Certigrav (12 percent by volume) when grinding finer than 5 micrometers. Grinding times up to 180 minutes were investigated with the mill operating at $340 \mathrm{rpm}$ in each case. The particle size distributions for sample increments taken during grinding were plotted in Figure 5. The tabulated distributions are given in Appendix D. A RosinRammler grid was used for the plots to show the coarser portion more clearly and, as shown, the plots were reasonably linear when using this system.

The particle size distributions were determined with a Micromeritics Model $5500 \mathrm{~L}$ SediGraph. This instrument tracks the Stokes gravitational settling of coal particles dispersed in a liquid. Light extinction versus particle size between 100 and 0.1 micrometers is plotted automatically. The weight or volume percent passing a size are calculated from the light extinction by a special computer program to compensate for the variation in the extinction coefficient with particle size. The amount of the coarsest 5 or 10 percent of the particle weight is not very well resolved by the SediGraph particle-size analyzer so the plus 20 micrometer and some of the plus 10 micrometer weights were determined using micromesh sieves. Use of these sieves permit the top size of each ground product to be established more accurately. The sieving was done first wet with toluene as the working fluid to remove most of the fines and finished dry with an Alpine Air-Jet sieve.

The 95, 80 and 50 percent passing sizes were interpolated from the curves in Figure 1 and plotted against grinding time (Figure 6). The plot for the 50-weight-percent passing size versus grinding time was essentjajly linear on a log-log scale indicating that the empirical Charles equation (8) can be applied to predict the grinding times required to achieve specified product sizes. (The Charles equation is $E=A d_{50}-\mathrm{a}$ where $E$ is the grinding energy or, as in this case, grinding time, $d_{50}$ is the 50 -percent passing particle size, and $A$ and a are empirical constants.)

A multiple regression analysis was made on the data to derive an expression for calculation of the required grinding time to achieve a specified product fineness. Details are in Appendix D. The correlation, which employed the Rosin-Rammler equation for the particle size distribution and the Charles equation for the grinding time versus particle size, was as follows:

$\ln t=5.305+1.030 \ln \ln (1 /(1-P))-1.359 \ln x-0.0333(\ln x)^{2}$

where $t$ is the grinding time in minutes, and $P$ is the weight fraction passing the specified particle size, $x$, in micrometers. 


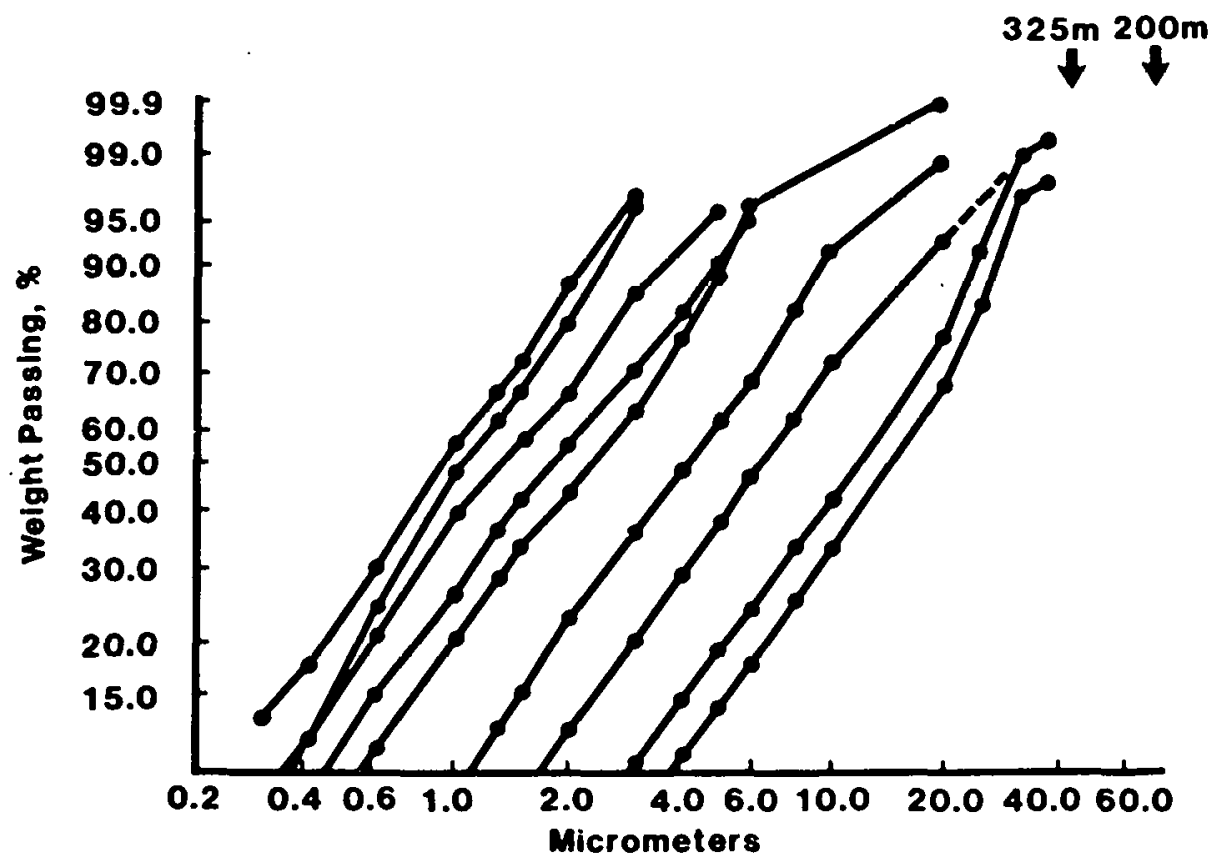

Figure 5. Particle Size Distributions of Slurry Increments Taken During Grinding of Illinois No. 6 Clean Coal in Stirred Ball Mill

Note: From left to right, size-distributions are after $180,120,90,60,40,20$, $10, b$, and 3 minutes of grinding. Plotted on Rosin-Rammler coordinates. 


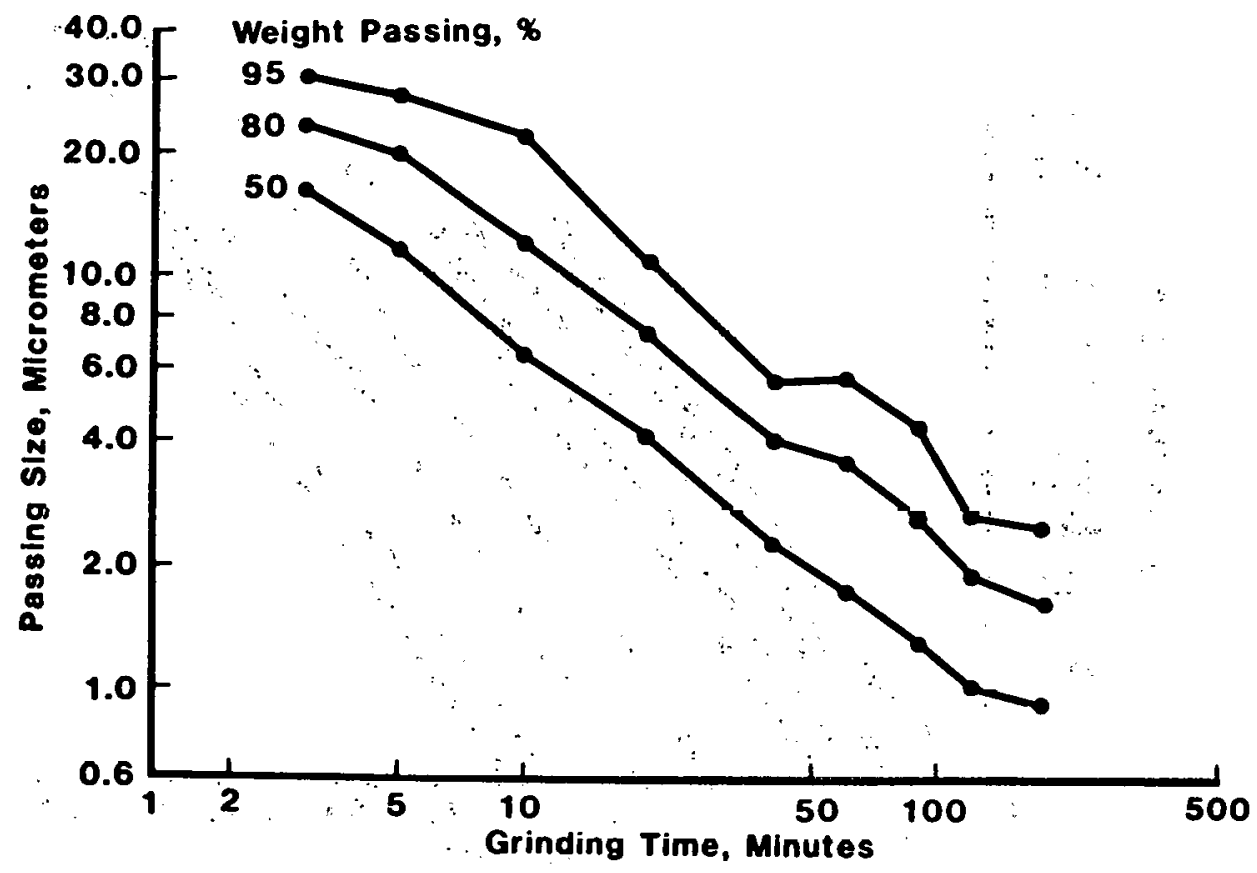

Figure 6. Particle Size Versus Time for Grinding Illinois No. 6 Clean Coal in a Stirred Ball Mill 
The multiple correlation coefficient, $R$ squared, was 98.7 percent. The presence of the $(\ln x)^{2}$ term indicated a small deviation from either the usual Charles equation or the Rosin-Rammler equation. The correlation was used to calculate the following grinding times for the required nominal products sizes.

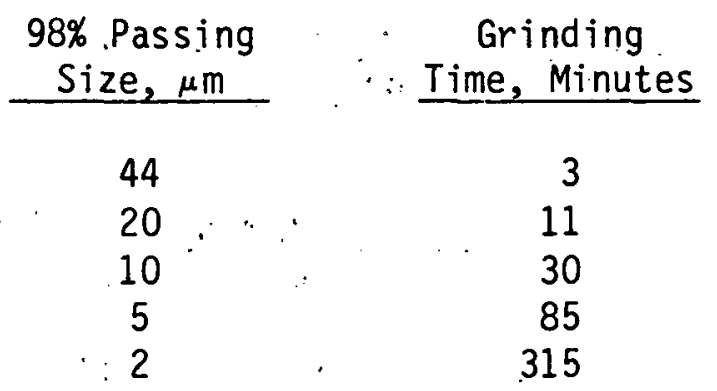

These products have been prepared from the Illinois No. 6 coal in the stirred ball mill and are available for the ultra-fine particle washability studies. Particle size distribution of these five products are given in Table 3 and appear to satisfy the project requirements for the liberation studies except that the product from the 315 minute grind did not quite reach the : target of 98 percent passing 2 micrometers.

\section{LIBERATION STUDIES BY HEAVY-LIQUID SEPARATION}

The basic method planned for quantifying mineral-matter liberation in ultra-fine coal will be the same as the method used for coarser coal, that is, heavy-liquid density separations on coal ground to nominally passing 44,20 , 10,5 , and 2 micrometers. The effectiveness of these separations will be demonstrated on the base-case Illinois No. 6 coal before continuing on to the other eight coals.

The heavy liquid separations were completed on the minus 44-micrometer (325-mesh) Illinois No. 6 clean coal. A modified centrifuge separation procedure at specific gravities of $1.3,1.4,1.6$, and 1.9 was adopted for the initial separations using Certigrav solutions. An International Model K centrifuge with a 6-place rotor was used with 250-ml Corning No. 1260 bottles to contain the samples. The steps in the separation were as follows:

1. Filter the Attritor-ground coal slurry and dry at $35-40^{\circ} \mathrm{C}$ until powdered coal is free flowing.

2. Weigh a 10-gram sample into each of six centrifuge bottles.

3. Add $200 \mathrm{ml}$ Certigrav solution, containing $500 \mathrm{ppm}$ Aerosol OT-S dispersant, to each bottle. 
Table 3. Particle Size Distributions of Illinois No. 6 Clean Coal Ground for Liberation Studies

Target Passing Size, $\mu \mathrm{m}$
Gioind Time, Minutes
Weight Passing, \%:
38 Micrometers
32
25
20
15
10
8
6
5
4
3
2
1.5
1.0
0.6
0.3

\begin{tabular}{|c|c|c|c|c|}
\hline \multicolumn{5}{|c|}{ Ground Coal Samples } \\
\hline 44 & 20 & 10 & 5 & 2 \\
\hline 3 & 1.1 & 30 & 85 & 315 \\
\hline
\end{tabular}

$98.2 *$

$97.4 *$

$84.5^{\star}$

68.1 99.9*

58.9 91.7*

$39.5 \quad 75.8$

$30.2 \quad 64.0$

$21.2 \quad 48.1$

16.5

12.5

8.7

5.4

3.8

2.3

1.1

0.8
40.1

30.6

21.6

12.8

8.9

5.0

2.1

1.1
$99.9 * 100.0 * 100.0 *$

87.6

74.8

62.3

47.5

30.9

22.8

13.9

6.2

1.3
92.6

$83.0 \cdot 98.7$

$62.5 \quad 85.8$

$\begin{array}{ll}48.2 & 64.0\end{array}$

$32.3 \quad 38.7$

$\begin{array}{ll}15.6 & 21.4\end{array}$

$5.8 \quad 12.1$

*Determined by micromesh sieving 
4. Mix well by stirring with brass rod and placing in an ultrasonic bath for 2 minutes.

5. Add additional Certigrav solution to balance bottles and holders and centrifuge for 45 minutes at $2000 \mathrm{rpm}$ (1064 g-force ${ }^{+}$tip).

6. Skim float coal into a paper-lined funnel filter.

7. Stir remaining slurry and place in ultrasonic bath for 2 minutes.

8. Re-balance bottles with additional Certigrav solution and centrifuge for 45 minutes.

9. Skim float coal into same filter as before.

10. Wash sink coal into another filter.

11. Wash both products with trichloroethane while on filter paper.

12. Dry products at $35-40^{\circ} \mathrm{C}$ and weigh.

The separations were begun at specific gravity 1.3 using about 400 grams of coal. The dried sink fractions were reprocessed in the successively higher density liquids.

To define liberation by particle size, the $1.3,1.3$ to 1.4 , and 1.4 to 1.6 specific-gravity float fractions were screened into plus 20-micrometer,

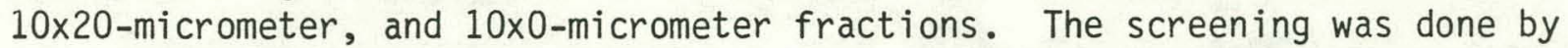
brushing and washing the undersize through vibrating micromesh sieves with toluene. The fractions were examined microscopically to determine the adequacy of the screening. Figures 7 and 8 are examples of these products. It was originally planned to screen the 1.6 to 1.9 specific gravity float and the 1.9 specific gravity sink as well but this was not practical since there were only 4 and 11 grams, respectively, of these two products available from the original 400 grams of feed coal. Approximately 4 grams of each sieve product were required for analyticai samples so about three times as much coal would need to have been processed in order to generate sufficient weights of sample for the size-fraction analyses. These higher specific-gravity products consist largely of liberated mineral-matter so alternative particle size distribution approaches will be investigated for them. 


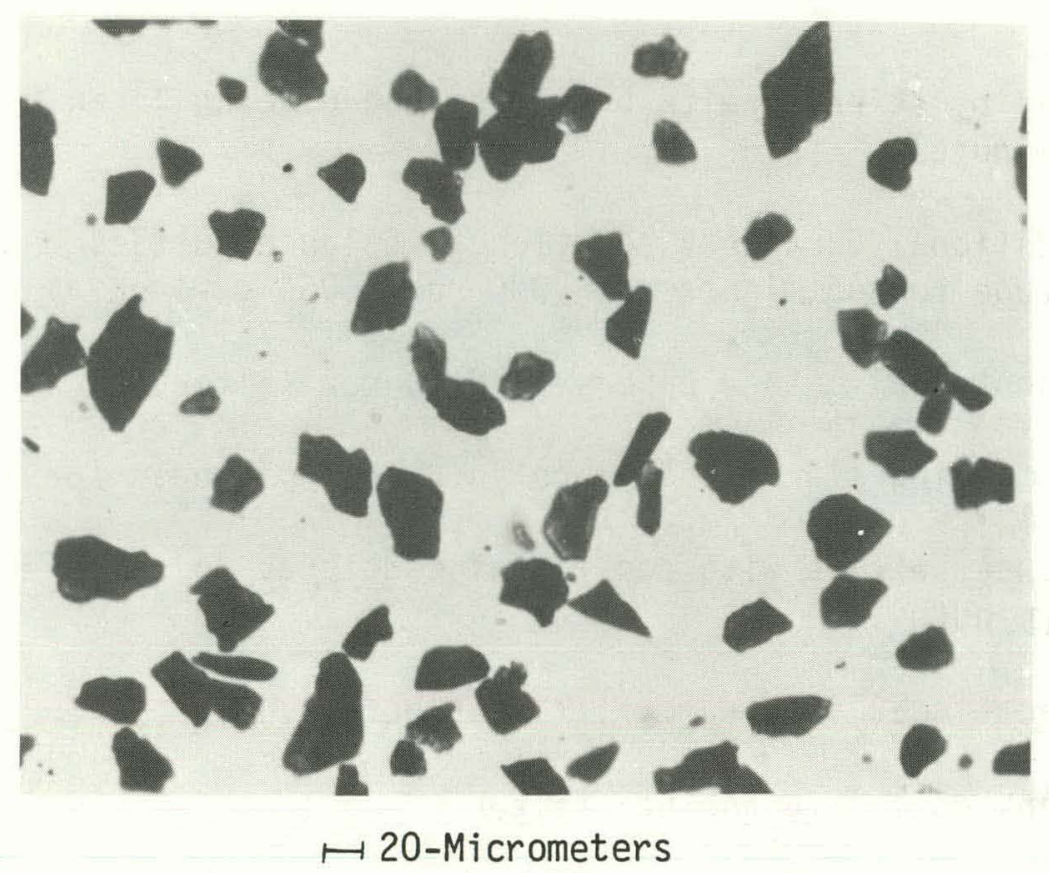

Figure 7. Plus 20-Micrometer Fraction from Wet Screening 44-Micrometer x 0 Illinois No. 6 1.3-Specific-Gravity Float Coal

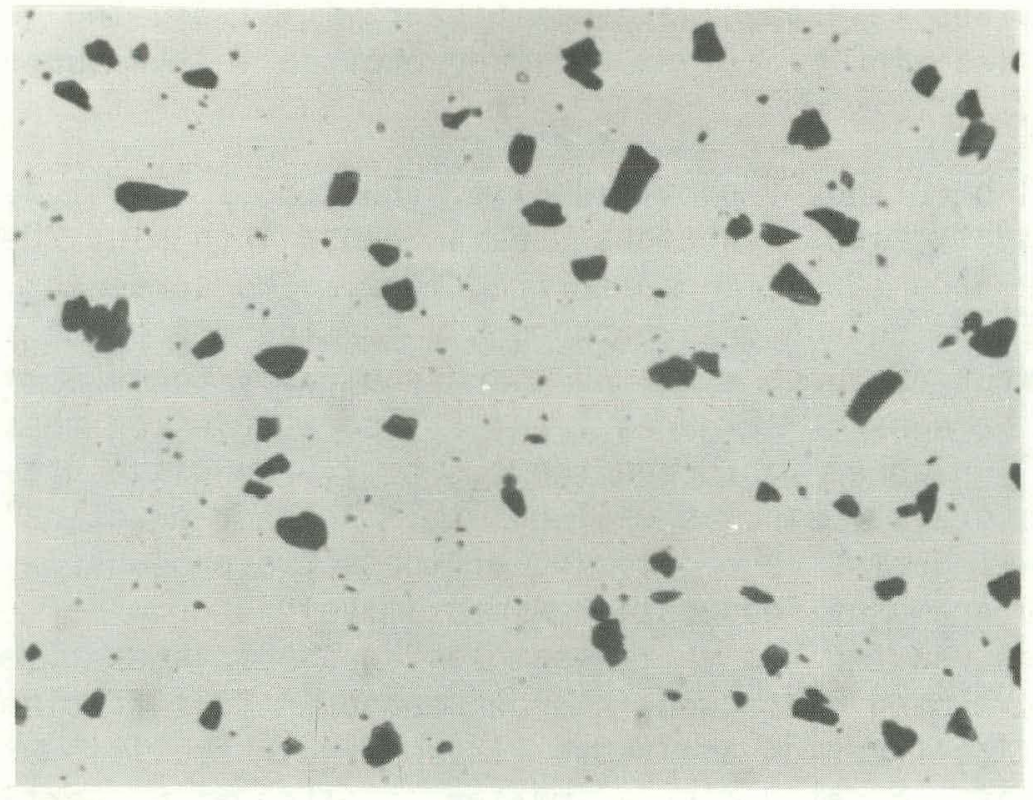

•20-Micrometers

Figure 8. 20-Micrometer $\times$ 10-Micrometer Fraction from Wet Screening 44-Micrometer x 0 Illinois No. 6 1.3-Specific-Gravity Float Coal

Note: The residual fine undersize visible in the picture can account for no more than 6 percent of the sample weight. 
There. was a good check between the micro-sieving and the SediGraph particle size analyses. The following is a comparison:

$\frac{\text { Weight Passing, Percent }}{\text { Sieving }}$

$\begin{array}{lll}20 \text { micrometers } & 70.4 & 68.1 \\ 10 \text { micrometers } & 38.7 & 39.5\end{array}$

The SediGraph analysis was for the entire sample but the sieving was for only the 1.6-specific-gravity cumulative float which represented 95.8 percent of the ground coal.

The various fractions were analyzed for ash, volatile-matter, forms of sulfur, and calorific value. The complete balance is in Appendix $B$. The following is a summary of these analyses for the 44-micrometer $\times 0$ Illinois No. 6 coal:

\begin{tabular}{|c|c|c|c|c|}
\hline \multirow{2}{*}{$\begin{array}{c}\text { Specific } \\
\text { Gravity }\end{array}$} & \multicolumn{4}{|c|}{ Cumulative Float } \\
\hline & Wt. \% & Ash \% & $S(T) \%$ & $S(P y) \%$ \\
\hline 1.30 & 46.3 & 1.14 & 1.82 & 0.07 \\
\hline 1.40 & 87.8 & 2.09 & 1.82 & 0.10 \\
\hline 1.60 & 95.8 & 3.12 & 1.85 & 0.15 \\
\hline 1.90 & 97.0 & 3.50 & 1.88 & 0.18 \\
\hline Calc. Feed & 100.0 & 5.65 & 2.21 & 0.57 \\
\hline
\end{tabular}

There was significantly improved liberation of mineral-matter at the 44micrometer grind compared to the 14-mesh (1180-micrometer) and 65-mesh (212micrometer) grinds as shown by the following comparisons:

\begin{tabular}{|c|c|c|c|c|c|}
\hline \multirow{2}{*}{$\begin{array}{c}\text { Nominal } \\
\text { Top Size, } \mu \mathrm{m}\end{array}$} & \multirow{2}{*}{$\begin{array}{l}\text { Specific } \\
\text { Gravity }\end{array}$} & \multicolumn{4}{|c|}{ Cumulative Float } \\
\hline & & Wt., \% & Ash, \% & $\underline{S(P y) \%}$ & Btu Rec. \% \\
\hline 1180 & 1.30 & 73.7 & 3.24 & 0.42 & 76.8 \\
\hline 212 & 1.30 & 70.5 & 2.33 & 0.18 & 74.8 \\
\hline 44 & 1.30 & 46.3 & 1.14 & 0.07 & 48.7 \\
\hline 1180 & 1.40 & 93.4 & 4.84 & 0.56 & 95.6 \\
\hline 212 & 1.40 & 88.6 & 3.64 & 0.31 & 92.7 \\
\hline 44 & 1.40 & 87.8 & 2.09 & 0.10 & 91.5 \\
\hline
\end{tabular}

This was particularly evident at the 1.40-specific-gravity separation where the weight and Btu yields were close to the same. The substantial drop in the weight reporting to the 1.30 float fraction is yet to be explained for the 44-micrometer $\times 0$ ground coal. Perhaps the mineral-matter was released as composite grains rather than free grains. 
Sieving the $1.3,1.4$, and 1.6 float products from the 44 -micrometer $\times 0$ coal produced some interesting results as shown in the following comparison:

\begin{tabular}{|c|c|c|c|c|c|c|c|c|}
\hline \multirow{2}{*}{$\begin{array}{r}\text { Mesh Size, } \\
\text { Micrometers }\end{array}$} & \multicolumn{2}{|c|}{ 1.30 Float } & \multicolumn{2}{|c|}{1.40 Float } & \multicolumn{2}{|c|}{1.60 Float } & \multicolumn{2}{|c|}{ Composite } \\
\hline & Wt. $\%$ & Ash \% & Wt. $\%$ & Ash $\%$ & Wt. $\%$ & Ash \% & wt.\% & Ash \% \\
\hline+20 & 46.3 & 0.94 & 12.5 & 5.60 & 21.0 & 16.62 & 29.6 & 2.73 \\
\hline $20 \times 10$ & 34.4 & 0.89 & 29.9 & 2.94 & 24.4 & 14.58 & 31.6 & 2.62 \\
\hline-10 & 19.3 & 2.05 & 57.6 & 2.73 & 54.6 & 13.26 & 38.8 & 3.82 \\
\hline Combined & 100.0 & 1.14 & 100.0 & 3.15 & 100.0 & 14.29 & 100.0 & 3.12 \\
\hline
\end{tabular}

Desliming the 1.30 float by sieving at 10 micrometers reduced the ash to about 0.9 percent. The slime will be examined microscopically to determine the nature of the ash in the silime. As shown, the particle-size distributions of the three heavy-liquid float products were also quite different. The greatest portion of the 1.30 float was coarser than 20 micrometers while the opposite was true of the 1.40 and 1.60 floats where the largest weight was in the minus 10-micrometer portion. A preliminary microscopic examination of the products suggested that the differences in weight distributions were related to the maceral distributions. The fusinite tended to be more friable than the vitrinite and concentrated in the finer size fractions. The fusinite also had a higher density than the vitrinite and was more likely to be associated with mineral-matter. For these reasons, fusinite tended to concentrate in the intermediate-density fractions whereas vitrinite concentrated in the coarser and the lower density fractions.

The centrifuge separations have been started on the base-case coal samples nominally passing 20,10,5, and 2 micrometers. The micromesh sieving step will be omitted from these tests. The sieving was a very tedious, time consuming operation requiring about 180 hnurs of teshnician time. The data generated will be examined very carefully to determine whether the effort is worth the cost and whether alternative methods would be more cost-effective for routine work and for the remaining coals in the-suite.

\section{REFERENCES}

1. Smit, F.J., "Ultra-Fine Coal Characterization, 1st Quarterly Report", Report DOE/PC/72007QTR-1 prepared for Pittsburgh Energy Technology Center by AMAX Extractive Research \& Development, Inc., June 8, 1984.

2. ASTM Standard Procedure D-388.

3. Montgomery, W.J., "Standard Laboratory Test Methods for Coal and Coke". Analytical Methods for Coal and Coal Products, Volume 1, (C. Karr, editor), Academic Press, New York, 1978, pp. 204-205. 
4. Davis, A., "The Reflectance of Coal", Analytical Methods for Coal and Coal Products, Volume 1, (C. Karr, editor), Academic Press, New York, 1978, pp. 27-81.

5. Chayes, F., "Petrographic Modal Analysis", John Wiley \& Sons, N.Y., 1956.

6. Dyrkacz, G.R., et al., "Variations in Properties of Coal Macerals, Elucidated by Density Gradient Separation", Chemistry and Characterization of Coal Macerals, American Chemical Society, Washington, D.C., 1984, pp. 65-77.

7. Odekirk, J.R., Naruk, S., and Taylor, P., "Computer Processing of Microscopic Point-Count Data: An Example", Process Mineralogy, TMS-AIME, Warrendale, PA, 1981, pp. 253-265.

8. Herbst, J.A., "Energy Requirements for the Fine Grinding of Coal in an Attritor", Report C00-4560-1 prepared for the U.S. Energy Research and Development Administration by the University of Utah, November 1978. 


\section{APPENDIX A \\ VITRINITE REFLECTANCE MEASUREMENTS}




\section{REFLECTANCE ANALYSIS}

WAL Batch: 011-105-01

Report of Analysis on Sample: Delta \#6

Mean-Maximum Vitrinite P.o: 0.64

Distribution of Vitrinite Reflectance Readings:

SRo

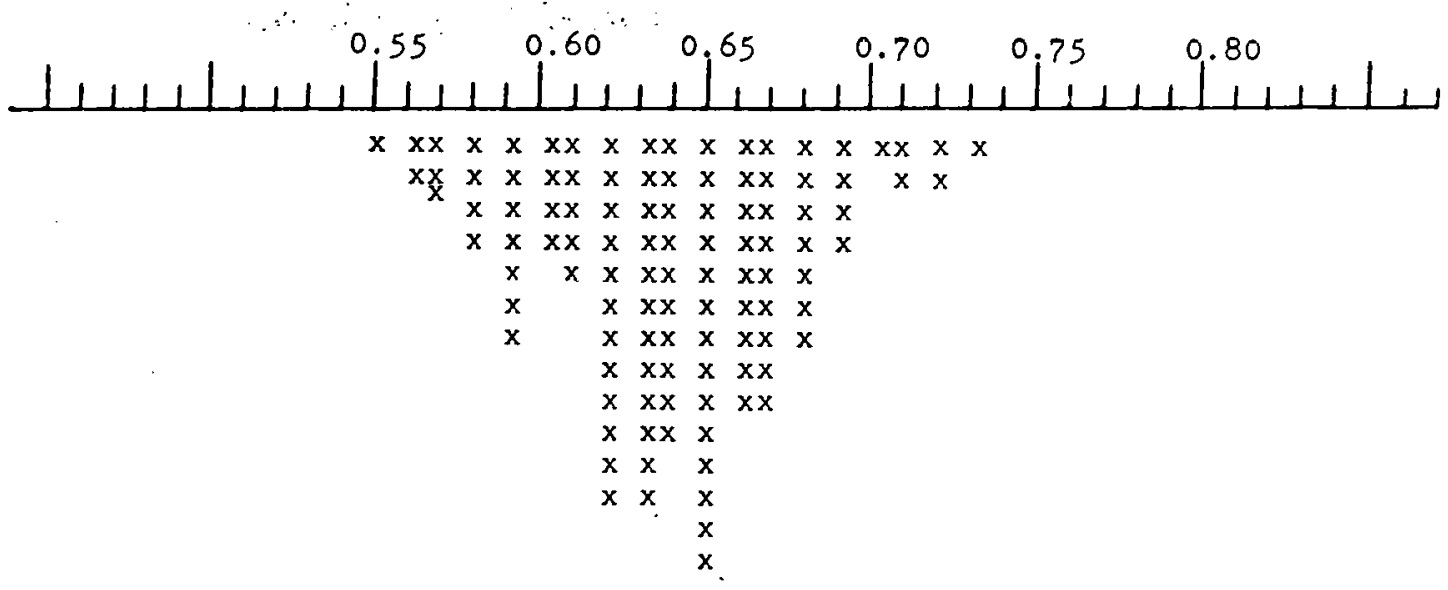

Number of

Counts

$($ Total $=$ 109)

V-Type Table for Vitrinites (=100\%)

$$
\frac{v-5}{15.6} \frac{v-6}{78.9} \frac{v-7}{5.5} \quad \underline{v-}
$$




\section{APPENDIX B}

WASHABILITY TEST DATA 
Table 4. Washability of 65 Mesh $\times 0$ Illinois No. 6 Cleaned Coal

Specific Gravity

Direct (Dry Basis)
Sink Float

$\begin{array}{rrrrrrrrr} & 1.30 & 70.5 & 2.33 & 37.66 & 1.54 & 0.012 & 0.18 & 14,276 \\ 1.30 & 1.40 & 18.1 & 8.74 & 36.21 & 1.98 & 0.045 & 0.82 & 13,256 \\ 1.40 & 1.60 & 7.1 & 19.25 & 31.92 & 2.42 & 0.082 & 1.54 & 11,483 \\ 1.60 & 1.90 & 1.5 & 35.78 & 31.37 & 4.23 & 0.208 & 3.84 & B, 682 \\ 1.90 & & 2.8 & 76.02 & 19.66 & 11.27 & 0.433 & 10.77 & 1,535\end{array}$

Cumulative Float (Dry Basis)

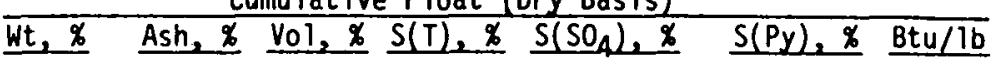

$\begin{array}{rrrrrrr}70.5 & 2.33 & 37.66 & 1.54 & 0.012 & 0.18 & 14,276 \\ 88.6 & 3.64 & 37.36 & 1.63 & 0.019 & 0.31 & 14,066 \\ 95.7 & 4.79 & 36.96 & 1.69 & 0.023 & 0.40 & 13,877 \\ 97.2 & 5.27 & 36.88 & 1.73 & 0.026 & 0.46 & 13,796 \\ 100.0 & 7.27 & 36.39 & 2.00 & 0.038 & 0.75 & 13,450\end{array}$


Table 5. Washability of 44-Micrometer $\times 0$ Illinois No. 6 Cleaned Coal

Specific Gravity

Direct (Dry Basis)

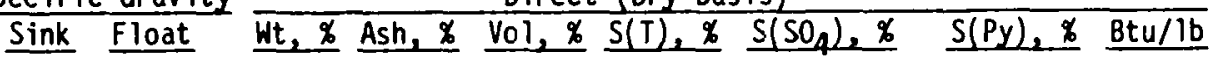

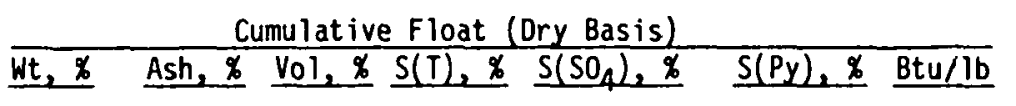

Plus 20 Micrometer, 1.6-Specific-Gravity Cumulative Float Fraction, 23.4 Weight Percent:

$\begin{array}{rrrrrrrrrrrrrrrr} & 1.30 & 75.7 & 0.94 & 41.59 & 1.81 & 0.006 & 0.05 & 14,253 & 75.7 & 0.94 & 41.59 & 1.81 & 0.006 & 0.05 & 14,523 \\ 1.30 & 1.40 & 18.3 & 5.60 & 43.09 & 1.90 & 0.005 & 0.31 & 14,065 & 94.0 & 1.85 & 41.88 & 1.83 & 0.006 & 0.10 & 14,433 \\ 1.40 & 1.60 & 6.0 & 16.62 & 34.76 & 2.44 & 0.026 & 1.04 & 12,301 & 100.0 & 2.73 & 41.46 & 1.86 & 0.007 & 0.16 & 14,305\end{array}$

$20 \times 10$ Micrometer, 1.6-Specific-Gravity Cumulative Float Fraction, 30.3 Weight Percent:

\begin{tabular}{|c|c|c|c|c|c|c|c|c|c|c|c|c|c|c|c|}
\hline & 1.30 & 52.6 & $\begin{array}{l}0.89 \\
2.94\end{array}$ & $\begin{array}{l}42.09 \\
39.73\end{array}$ & $\begin{array}{l}1.79 \\
1.76\end{array}$ & 0.008 & 0.05 & $\begin{array}{l}14,536 \\
14,356\end{array}$ & $\begin{array}{l}52.6 \\
93.5\end{array}$ & $\begin{array}{l}0.89 \\
1.79\end{array}$ & $\begin{array}{l}42.09 \\
41.06\end{array}$ & $\begin{array}{l}1.79 \\
1.78\end{array}$ & $\begin{array}{l}0.008 \\
0.012\end{array}$ & $\begin{array}{l}0.05 \\
0.05\end{array}$ & $\begin{array}{l}14,536 \\
14,457\end{array}$ \\
\hline 1.40 & 1.60 & 6.5 & 14.58 & 35.23 & 2.10 & 0.036 & 0.67 & 12,485 & 100.0 & 2.62 & 40.68 & 1.80 & 0.014 & 0.09 & 14,328 \\
\hline
\end{tabular}

10-Micrometer $\times 0,1.6-$ Specific-Gravity Cumulative Float Fraction, 37.1 Height Percent:

$\begin{array}{rrrrrrrrrrrrrrrrrr} & 1.30 & 24.0 & 2.05 & 41.82 & 1.92 & 0.019 & 0.15 & 14,393 & 24.0 & 2.05 & 41.82 & 1.92 & 0.019 & 0.15 & 14,393 \\ 1.30 & 1.40 & 64.1 & 2.73 & 39.23 & 1.84 & 0.028 & 0.13 & 14,226 & 88.1 & 2.54 & 39.94 & 1.86 & 0.026 & 0.14 & 14,271 \\ 1.40 & 1.60 & 11.9 & 13.26 & 35.19 & 2.08 & 0.061 & 0.65 & 12,533 & 100.0 & 3.82 & 39.37 & 1.89 & 0.030 & 0.20 & 14,065\end{array}$

44-Micrometer $\times 0$, Composite, 100.0 Weight Percent:

\begin{tabular}{|c|c|c|c|c|c|c|c|c|c|c|c|c|c|c|c|}
\hline 3 & $\begin{array}{l}1.30 \\
1.40\end{array}$ & $\begin{array}{l}46.3 \\
41.5\end{array}$ & $\begin{array}{l}1.14 \\
3.15\end{array}$ & $\begin{array}{l}41.81 \\
39.86\end{array}$ & $\begin{array}{l}1.82 \\
1.82\end{array}$ & $\begin{array}{l}0.009 \\
0.022\end{array}$ & $\begin{array}{l}0.07 \\
0.13\end{array}$ & $\begin{array}{l}14,502 \\
14,245\end{array}$ & $\begin{array}{l}46.3 \\
87.8\end{array}$ & $\begin{array}{l}1.14 \\
2.09\end{array}$ & $\begin{array}{l}41.81 \\
40.89\end{array}$ & $\begin{array}{l}1.82 \\
1.82\end{array}$ & $\begin{array}{l}0.009 \\
0.015\end{array}$ & $\begin{array}{l}0.07 \\
0.10\end{array}$ & $\begin{array}{l}14,502 \\
14,380\end{array}$ \\
\hline 1.40 & 1.60 & 8.0 & 14.29 & 35.11 & 2.16 & 0.048 & 0.74 & 12,472 & 95.8 & 3.12 & 40.40 & 1.85 & 0.018 & 0.15 & 14,219 \\
\hline 1.60 & 1.90 & 1.2 & 35.66 & 27.95 & 3.93 & 0.084 & 2.75 & 8,847 & 97.0 & 3.50 & 40.25 & 1.88 & 0.019 & 0.18 & 14,155 \\
\hline 19 & & 3.0 & 74.87 & 19.90 & 13.08 & 0.177 & 12.90 & 2,177 & 100.0 & 5.65 & 39.64 & 2.21 & 0.024 & 0.57 & 13,795 \\
\hline
\end{tabular}




\section{APPENDIX C}

MACERAL/MINERAL DISTRIBUTION TABLES 
Table 6. Composite Mineralogical Balances for $14 \mathrm{M} \times 0$ Whole Seam Ill inois No. 6 Coal.

\section{Component}

Vitrinite

Inertinite

Exinite

Mineral-Matter:

Lenser

Dispersed

W/Fusinite

Cleats

Free

Pyrite:

Framboids

Crystals

W/Fusinite

Veins

Free

Total

Weight, $\%$ of

Total

$14 M \times 1$
69.32
4.32
3.42

\subsection{2}

5.32

1.35

0.51

4.06

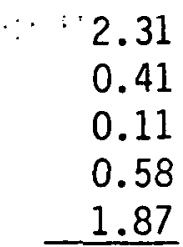

100.00

80.40
Weight, Percent ${ }^{\mathrm{a}}$

$\underline{100 M \times 0 \quad \text { Composite }}$

62.65

7.76

2.59

68.01

4.99

3.26

2.61

5.42

1.81

0.78

8.10

5.67

5.34

1.44

0.56

4.86

2.76

2.40

0.88

0.14

0.50

0.11

0.68

2.18

1.05

3.45

100.00

100.00

19.60

100.00

${ }^{a}$ Calculated from point-count data in Tables 7 and 8. 
Table 7. Foint-Count Mineralogical Balances for $14 M \times 100 M$ whole Seam

$$
\text { Illinois No. } 6 \text { Coal }
$$

Component

Vitrinite Inertinite

Exinite

U $\frac{1.3 \text { Sp. Gr. Float }}{\text { Counts Wt. } \%} \quad \frac{1.3-1.4 \text { Sp. Gr. }}{\text { Counts Wt. } \%} \quad \frac{1.4-1.5 \text { Sp. Gr. }}{\text { Counts Wt. } \%}$

891
20
53

10
21
1
0

Framboids

Crystals

W/Fusinite

Veins

Free

Totals

Weight, $\%$ of

Total

86.06

832

$76.44 \quad 690$

$5.38 \quad 139$

59.76

12.59

$\begin{array}{ll}2.02 & 56 \\ 4.69 & 34\end{array}$

2.86

39

3.10

$\begin{array}{ll}5.16 & 49\end{array}$

$3.87 \quad 39$

1.66

1.11
0.00

8.52

6.78

3.30

0.87

0.20

0.00

0.00

$\begin{array}{lll}3.17 & 15 & 3.44\end{array}$

$\begin{array}{lll}0.35 & 3 & 0.98\end{array}$

0.00

0.00

0.00

0.00

0.00

0.00

0.66

0.00

0

100.00

1000

$100.00 \quad 1000$

100.00

26.051

4.045

48.235
1.5-1.65 Sp. Gr.

4.013

52.03

13.32

1.65-1.9 Sp. Gr.

Counts Wt., $\%$

Counts . Gr. Sink

625
153

571
180

45.76

233

30

13.54

9.02

3.34

0.67

87

$\begin{array}{ll}50 & 14.00 \\ 47 & 4.05\end{array}$

$47 \quad 7.56$

7.56
1.13

1.13
0.00

3.53
0.63

0.32

0.32

0.00

2

$5.31 \quad 26$

$0.61 \quad 8$

0.30

0.00

0.00

2
20
82

82

$100.00 \quad 1000$

12.46

2.57

19.53

10.09

9.04
$8 \quad 2.04$

$8 \quad 0.86$

4

04


Table 8. Foint-Count Mineralogical Balances for $100 \mathrm{M} \times 0$ Whole Seam

$$
\text { lllinois No. } 6 \text { Coal }
$$

Component

\section{Vitrinite}

Inertinite

Exinite

N

Lenses

Dispersed

W/Fusinite

Cleats

Free

Pyrite:

Framboids

Crystals

W/Fusinite

Veins

Free

Totals

Weight, $\%$ of

Total

1.3

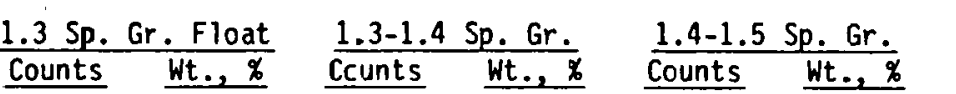

17 Counts

$917 \quad 88.87$

18
34

$5 \quad 0.97$

$21 \quad 4.09$

10.20

$0 \quad 0.00$

0.00

$\begin{array}{ll}4 & 1.03 \\ 0 & 0.00\end{array}$

$0 \quad 0.00$

$0 \quad 0.00$

$0 \quad 0.00$

1000

\begin{abstract}
$-00.00$
\end{abstract}
1000

Wt., \%

$\begin{array}{rr}7 \subseteq 2 & 73.53 \\ \subseteq 0 & 8.73 \\ 52 & 4.43\end{array}$

598

54.27

27.51

$3.35 \quad 29$

$3.73 \quad 18$

$1.68 \quad 16$

0.75

0.00

5.28

3.28

.2 .92

2.00

$14 \% 3.45$

3.45
0.35

0.00

0.00

10 .

2.41

0.00

0.00

0.00

0.00

$100.00 \quad 1000$

100.00

$\frac{1.5-1.65}{\text { Counts }}$

532
293

32

1000

8.647

18.443

5.773

43.992

\begin{abstract}
18.443
\end{abstract}
Sp. Gr

Wt. $2 \%$

45.18

26.02
2.18

\subsection{6}

7.67

4.09

4.09
3.58

3.58
0.00

5.18
0.32

0.32

0.32

0.00
0.00

$\frac{1.65-1.9 \mathrm{Sp} . \mathrm{Gr}}{\text { Counts }}$

Counts

4.23

41.23

$274: \quad 23.38$

29
2.17

60
43

$60-83$
43

$\begin{array}{lll}7.05 & 104 & 2.12\end{array}$

$8.03 \quad 33 \quad 10$

$\begin{array}{lll}8.03 & 33 & 3.18 \\ 1.97 & 10 & 0.97\end{array}$

$\begin{array}{lrr}1.97 & 10 & 0.97 \\ 0.00 & 436 & 42.10\end{array}$

$\frac{1.9 \mathrm{Sp} \cdot \mathrm{Gr} \cdot \operatorname{Sink}}{\text { Counts }}$

$117 \quad 5.63$

$57 \quad 2.87$

.63

04
18
97
10

$\begin{array}{lll}5.41 & 39 & 4.97\end{array}$

$0.62 \quad 22 \quad 4.01$

$0.31 \quad 3 \quad 0.55$

$\begin{array}{rrr}0.00 & 30 & 5.46 \\ 0.00 & 123 & 17.92\end{array}$

$\begin{array}{lllll}100.00 & 1000 \quad 100.00 \quad 1000 \quad 100.00\end{array}$
3.892

19.253 
Table 9. Composite Mineralogical Balances for $14 \mathrm{M} \times 0$ Illinois No. 6 Clean Coal

Component

Vitrinite

Inertinite

Exinite

Mineral Matter:

Lenses

Dispersed

W/Fusinite

Cleats

Free

Pyrite:

Framboids

Crystals

W/Fusinite

Veins

Free

Totals

Weight, $\%$ of

Total

\begin{tabular}{cc}
\multicolumn{3}{c}{ Weight, Percent ${ }^{\mathrm{a}}$} \\
\hline$\underline{14 M \times 100 M} \quad \underline{100 M \times 0} \quad$ Composite
\end{tabular}

$$
84.55
$$

4.03

3.86

1.89

2.95

0.61 .

0.64

0.25

0.88

0.22

$\mathrm{Tr}$

0.07

0.05

100.00

82.90

17.10

1.12

0.25

0.04

0.09

0.58

100.00

100.00

${ }^{a}$ Calculated from point count data in Tables 10 and 11.
83.50

4.47

3.88

1.82

2.76

0.79

0.75

0.66

0.92

0.23

0.01

0.07

0.14

100.00 
Table 10. Point-Count Mineralogical Balances for $14 M \times 100 M$ Whole Seam Illinois No. 6 Coal

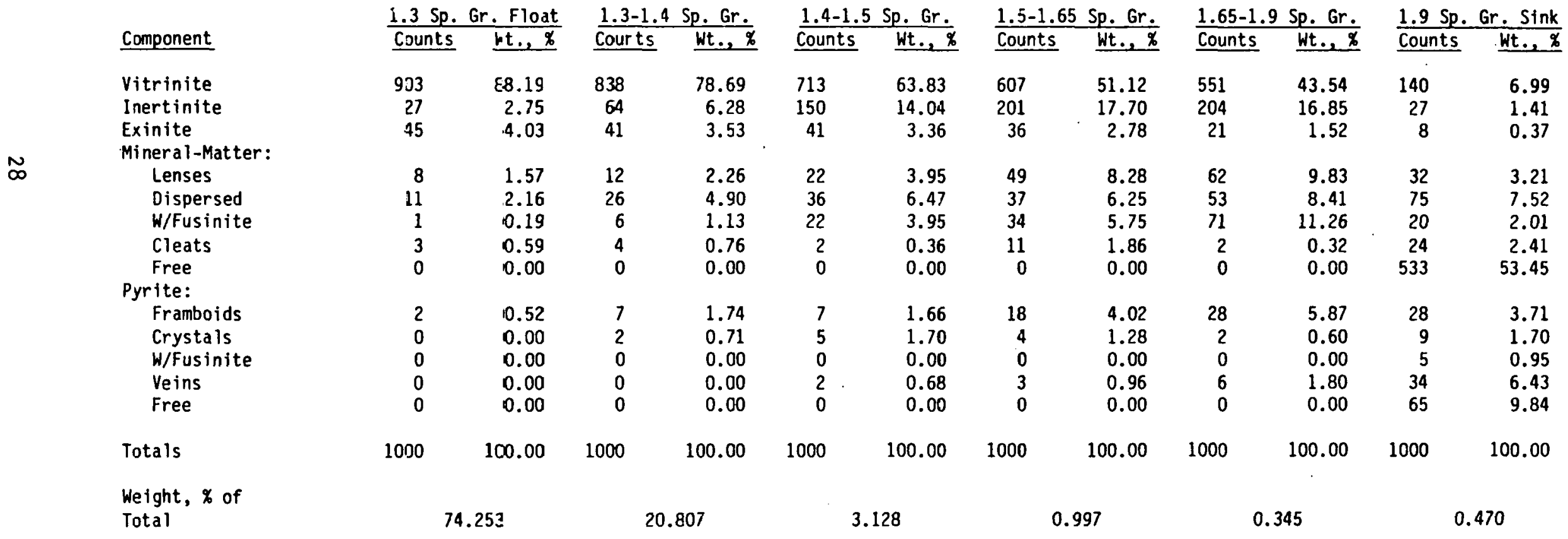


Tat 1e 11. Point-Count Mineralogical Balances for $100 \mathrm{M} \times 0$ 111 ino is No. 6 Coal

Component
Vitrinite
Inertinite
Exinite
Mineral-Matter:
Lenses
Dispersed
W/Fusinite
Cleats
Free
Pyrite:
Framboids
Crystals
W/Fusinite
Veins
Free

Totals

Weight, $x$ of

1.

\begin{tabular}{r}
1.3 \\
\hline 90 \\
27 \\
4 \\
\\
4 \\
100
\end{tabular}

\begin{tabular}{l}
.3 Sp. \\
\hline Counts \\
\hline 905 \\
27 \\
49 \\
4 \\
5 \\
4 \\
5 \\
0 \\
1 \\
0 \\
0 \\
0 \\
0 \\
000
\end{tabular}

\section{1inois No. 6 Coal}

$\frac{\text { Gr. Float }}{\text { Wt., } \%}$

Wt.. \%

Counts 1.4 Sp. Gr.

2.78

755

755
146
42

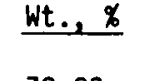

70.93

14.34

$\frac{1.4-1.5 \text { Sp. Gr. }}{\text { Counts }}$

583

0.79

$0.98 \quad 17$

$0.79 \quad 11$

0.98

0.00

0.26

0.00

0.00

0.00

0.00

100.00

71.190

13.898

3.02

3.21

2.07

1.32
0.00

583
292

52.49

Counts

548

548
274
35

Wt., $\dot{\phi}$

46.73

24.43

$\frac{1.65-1.9 \text { Sp. Gr. }}{\text { Counts }}$

Counts

27.49

35

2.74

265

41.44

41.44

22.12

1.10

5.13

3.85

13.79

3.25
8.22

8.22
1.88

32
24

86

4.34

3.07
0.00

11
0

0.00

1.49

0.00

0.00

143.34

$1 \quad 0.34$

3.34
0.34
0.00

0.00

0.00
0.00

$\begin{array}{rr}24 & 5.43 \\ 1 & 0.32\end{array}$

0.32

0.00

0.00

0

100.00

0

0.00

16
0

2.56
0.00

6.99

2.42

0.60

0.00

0.00

$100.00 \quad 1000$

100.00

5.190

\begin{abstract}
3.190

.
\end{abstract}

1.342

5.190 
APPENDIX D

CORRELATION OF STIRRED-BALL MILL GRINDING DATA 


\section{CORRELATION OF STIRRED GRINDING DATA}

The Minitab multiple-regression program was used to correlate the stirred-ball mill grinding data. The particle-size distributions after grinding times ranging from 3 minutes to 180 minutes are tabulated in Table 12. Only the upper 90 percent of the weight distributions were used for the regression analysis. A sieve analysis of the feed coal is given in Table

The correlation was based upon the Charles equation (8):

$$
E=A\left(d_{50} p^{-a}-d_{50} f^{-a}\right)
$$

where $E$ is the energy applied per unit mass, $d_{50 p}$ and $d_{50 f}$ are the 50 percent passing particle sizes of the product and feed, respectively, and $A$ and a are

Table 12. Particle Size Distributions of Ground Coal

\begin{tabular}{|c|c|c|c|c|c|c|c|c|c|}
\hline \multirow{2}{*}{$\begin{array}{c}\text { Grinding Time, } \\
\text { Minutes }\end{array}$} & \multicolumn{9}{|c|}{ Ground Coal Samples } \\
\hline & 3 & 5 & 10 & 20 & 40 & 60 & 90 & 120 & 180 \\
\hline t. Passing, $\%$ & & & & & & & & & \\
\hline $38 \mu \mathrm{m}$ & 98.2 & 99.3 & & & $\therefore$ & & & & $\sigma^{\circ}$ \\
\hline 32 & 97.4 & 99.1 & & & & & & & \\
\hline 25 & 84.5 & 92.8 & & & & & & & \\
\hline 20 & 68.1 & 78.1 & 94.0 & 99.0 & 99.9 & tr & & & \\
\hline 15 & 58.9 & 58.9 & 87.7 & & & & & & \\
\hline 10 & 39.5 & 43.2 & 73.0 & 92.8 & & & & & \\
\hline 8 & 30.2 & 33.8 & 61.3 & 84.2 & & & & & \\
\hline 6 & 21.2 & 24.8 & 47.7 & 69.2 & 96.8 & 96.4 & & & \\
\hline 5 & 16.5 & 20.0 & 38.8 & 60.0 & 89.6 & $90.9^{\circ}$ & 96.4 & & \\
\hline 4 & 12.3 & 15.0 & 30.1 & 49.3 & 77.9 & 84.0 & 93.5 & & \\
\hline 3 & 8.7 & 10.8 & 21.1 & 36.9 & 62.7 & 71.6 & 86.8 & 97.5 & 96.9 \\
\hline 2 & 5.4 & 6.3 & 12.8 & 24.0 & 44.9 & 55.3 & 66.0 & 81.3 & 88.2 \\
\hline 1.5 & 3.8 & 3.9 & 8.9 & 16.2 & 34.3 & 43.1 & 56.5 & 66.3 & 74.6 \\
\hline 1.0 & 2.3 & 2.1 & 4.5 & 9.4 & 21.8 & 26.6 & 39.8 & 48.9 & 55.5 \\
\hline 0.6 & 1.1 & 0.9 & 2.5 & 4.2 & 11.7 & 15.6 & 21.7 & 25.3 & 32.0 \\
\hline 0.3 & 0.8 & 0.6 & 1.2 & 1.5 & 4.8 & 5.1 & 7.3 & 8.1 & 14.0 \\
\hline
\end{tabular}


Table 13. Particle Size Distribution 80M $\times 0$ Illinois No. 6 Feed Coal for Stirred-Ball-Mill Grinding Tests

\begin{tabular}{ccc} 
& Sieve & Weight \\
\hline US Mesh & $\frac{\text { Micrometers }}{1}$ & $\frac{\text { Passing, } \%}{}$ \\
\hline 100 & 150 & 91.0 \\
140 & 106 & 76.4 \\
200 & 75 & 56.3 \\
270 & 53 & 45.2 \\
325 & 45 & 36.2 \\
400 & 38 & 28.2 \\
& & $\left(d_{50}=61\right.$ micrometers $)$
\end{tabular}

empirical constants. From Herbst's measurements ${ }^{(8)}$, the power draft of a stirred-ball mill. appears to be essentially constant after the first few minutes of grinding so for a batch grind as in this work, the energy term, $E$, can be replaced with the grinding time, $t$. Also for large ratios of reduction, the $d_{50 f}{ }^{-a}$ term for the feed is small compared to the similar term for the product so it can be ignored. Furthermore, for the purposes of this correlation, it will be assumed that any consistent weight percent passing size can be used for the particle size parameter not just the 50 percent passing size. The essentially "parallel" nature of the plotted particle size distribution curves in Figure 1 support this assumption. With these assumptions the modified Charles equation becomes

$$
t=A d^{-a}
$$

which is a linear plot on $\log$ - log coordinates.

The particle size distributions for the ground coal were assumed to follow the Rosin-Rammler equation.

$$
P=1-e^{-(x / k)^{n}}
$$


where $P$ is the weight fraction passing a particle size, $x$, and $n$ is an empirical constant. The term, $k$, is the particle size at which the particle size distribution intercepts the 63.2 weight percent passing level. The Rosin-Rammler equation can be solved for $k$ by rearranging the terms and taking the natural logarithms:

$$
\begin{aligned}
& e^{(x / k)^{n}}=1 /(1-P) \\
& (x / k)^{n}=\ln (1 /(1-P)) \\
& x / k=(\ln (1 /(1-P)))^{1 / n} \\
& k=x(\ln (1 /(1-P)))^{-1 / n}
\end{aligned}
$$

If the 63.2 percent passing level is selected for use in the Charles equation, $k$ can be substituted for $d$ in equation 3 giving

$$
t=A x^{-a}(\ln (1 /(1-P)))^{a / n}
$$

By taking the logarithm of both sides, this equation becomes a form suitable for use with least-square multiple regression correlations:

$$
\ln t=\ln A+(a / n) \ln \ln (1 /(1-P))-a \ln x
$$

and which relates grinding time to a target weight fraction, $P$, passing a specified particle size, $x$. To test for non-linearity, cross products and squares of the two independent variables, $\ln x$ and $\ln \ln (1 /(1-P))$, were also included in some of the regression calculations. The best fit was with the following equation:

$$
\ln t=5.305+1.030 \ln \ln (1 /(1-P))-1.359 \ln x-0.0333(\ln x)^{2}
$$

where $t$ is time in minutes, and $P$ is the weight fraction passing any particle size, $x$, in micrometers. The multiple $R^{2}$ for the regression equation was $y \dot{8} .7$ percent and the standard error was 0.154 ( \pm 15 percent) with 66 degrees of freedom. The t-ratios for the constant and coefficients were as follows:

\begin{tabular}{lcc} 
Term & Value & $\frac{\text { t-ratio }}{147.7}$ \\
\hline Constant & 5.305 & 49.3 \\
$\ln \ln (1 /(1-P))$ & 1.030 & 34.1 \\
$\ln x$ & -1.359 & 2.54 \\
$(\ln x)^{2}$ & -0.0333 &
\end{tabular}

These values were all significant at the 99-percent confidence level. 
